УДК 78
DOІ https://doi.org/10.31723/2524-0447-2021-32-1-25

Валентина Борисівна Васильєва

ORCID: 0000-0002-3883-0005

народна артистка України, професор,

професор кафедри сольного співу

Одеської національної музичної академії імені А. В. Нежданової pobeda-vik@ukr.net

\title{
ДУАЛІЗМ У МУЗИЧНО-ХУДОЖНЬОМУ ВТІЛЕННІ ОБРАЗУ АЗУЧЕНИ В ОПЕРІ «ТРУБАДУР» ДЖ. ВЕРДІ: ТЕХНІЧНІ РЕКОМЕНДАЦІЇ
}

Метою статті є розгляд музичного втілення образу Матері в драматургічній основі твору, характеристики образу та як від драматургії твору залежить сценічний образ, технічні прийоми у виконанні оперної партії, а саме аналіз на прикладі показової у иьому аспекті партії Азучени в опері «Трубадур» Джузеппе Верді у виконавському контексті. Також метою статті є розгляд можливостей голосу $і$ і технічних прийомів для формування образу Матері в європейській оперній музиці $X I X-X X$ століть, виявлення типових ознак паралельних драматургічних ліній. Методологія статті - суміщення принципів історико-культурологічного та типологічного методів, а також стильового аналізу виконання. Наукова новизна полягає в такому: на погляд автора статті, y сучасних дослідженнях оперного мистецтва не досить досліджені дві паралельні драматичні лінії в образі Азучени опери «Трубадур» Джузеппе Верді. У виставі по черзі одна драматична лінія домінує над другою чи виступають рівнозначно, об'єднуючись. У иьому полягає велика складність для виконавиці ролі. У цій статті відбувається дослідження дуалізму у музично-художньому втіленні, тобто об'єднання в одній ролі образів Матері та Доньки, які співіснують в одній героїні. Тому виконавське висвітлення вказаної теми суттєво доповнює музикознавчу теорію оперного мистецтва та його виконавського аспекту. Висновки. У цій статті було виявлено музично-художне втілення дуалізму в образі Азучени в опері «Трубадур» Джузеппе Верді; розкрито та систематизовано великий досвід роботи автора над сиенічним образом, вокальними труднощами, які виникають у недосвідченої виконавиці, технічні рекомендації щодо підготовки партії, вміння опанувати психологічне навантаження; була досягнута мета автора як співачки передати свій досвід наступному поколінню виконавців партії Азучени в опері «Трубадур» Джузеппе Верді. Практична цінність статті визначається можливістю використання ї̈ матеріалів у класі сольного співу, а так

(C) Васильєва В. Б., 2021 
само для курсів теорії та історії виконавства у вищій і середній музичній школі. Статтю написано на прикладі власного виконання автора партії Азучени.

Ключові слова: образ Матері, архетипічність образу, дуалізм, західноєвропейська опера.

Vasilyeva Valentina Borysivna, People's Artist of Ukraine, Professor, Professor at the Department of Solo Singing of the Odessa National A. V. Nezhdanova Academy of Music

Dualism in the musical and artistic embodiment of the image of Azuchena in the opera "Troubadour" by G. Verdi: technical recommendations

The aim of the article is to consider the musical embodiment of the image of the Mother in the dramatic basis of the work, the characteristics of the image, and how the dramatic image of the work depends on the stage image, techniques in performing the opera part, namely analysis on the example Verdi in the performing context. Also, the aim of the article is consideration of the possibilities of voice and techniques for the formation of the image of the Mother in the European opera music of the XIX-XX centuries, the identification of typical features of parallel dramatic lines. The methodology of the article is a combination of the principles of historical-cultural and typological methods, as well as stylistic analysis of performance. The scientific novelty is as follows: in the opinion of the author of the article, in modern studies of opera, two parallel dramatic lines in the image of Azuchena's opera "Troubadour" by Giuseppe Verdi are not sufficiently studied. In a play, in turn, one dramatic line dominates over another or they act equally, uniting. This is a great challenge for the performer. This article examines the dualism in the musical-artistic embodiment, that is, the unification in one role of the images of Mother and Daughter who coexist in one heroine. Therefore, the performance coverage of this topic significantly complements the musicological theory of opera and its performance aspect. Conclusions. This article reveals the musical and artistic embodiment of dualism in the image of Azuchena in Giuseppe Verdi's opera The Troubadour; extensive experience of the author's work on the stage image, vocal difficulties that arise in an inexperienced performer, technical recommendations for party preparation, the ability to master the psychological load are revealed and systematized; the author's goal was achieved as a singer to pass on his experience to the next generation of performers of the Azuchena part in Giuseppe Verdi's opera The Troubadour. The practical value of the article is determined by the possibility of using its materials in the class of solo singing, as well as for courses in theory and history of performance in higher and secondary music school. The article is written on the example of the author's own performance of Azuchena's party.

Key words: image of the Mother, archetypal image, dualism, Western European opera.

Актуальність теми дослідження. Питання про музично-художні принципи втілення теми дуалізму образу Азучени в 
опері «Трубадур» Джузеппе Верді досі не було об’єктом спеціального дослідження. Виходячи з того, що образ Матері та Доньки в одній особі в європейській опері малодосліджений серед стійких типів героїв, але завжди присутній в оперних сюжетах, дослідження дуалізму в образі як особливого і типологічно стійкого явища $\epsilon$ актуальним, на переконання автора.

Мета дослідження - виявлення характерних рис і особливостей функціонування образу Матері в оперній музиці як певного типу оперної героїні, що дає виконавцю можливості усвідомлення його як цілісного явища. А це, своєю чергою, зумовлює логіку виконавської інтерпретації і принципи формування виконавської концепції. Тому звернення до такої теми може хоча б у малому ступені заповнити наявні прогалини у сучасному вивченні оперного мистецтва.

Виклад основного матеріалу. Тема материнства і образ Матері є однією з найбільш стійких сюжетних ліній в істоpiї європейського оперного мистецтва. Архетипічність образу Матері зумовлює його незмінні, стійкі риси (жіночність, красу, ідеальність), які зберігаються протягом історичного розвитку і в розмаїтті творчих заломлень. Ці стійкі риси утворюють специфічні особливості художнього образу Матері в різних видах мистецтва.

Опера - жанр перш за все музичний і центральним елементом у ній є голос співака. Характер героя, стилістика епохи, відтінки емоцій - усе це втілюється в голосі, в його невичерпних фарбах. В оперній практиці використовуються такі поняття, як оперні амплуа, вокальні амплуа [14]. Вони несуть у собі різні аспекти сенсу. Так, у плані оперних амплуа мається на увазі рід ролей, пов'язаних з певним типом голосу.

До кінця XIX століття складається поняття про оперну майстерність, що органічно поєднує вокальні та акторські навички. Вимоги до виконавців - оркестру, хору, солістів випливають 3 уявлень про оперний театр як театр музично-драматичний. Вердіївська драма, що досягла вершин вокально-драматичної виразності, вимагала від співаків більшої напруги голосового апарату, більшої насиченості, мощі, барвистості звуку, особливо у верхньому регістрі, на який лягло основне навантаження в кульмінаційних моментах не тільки в арії, але і в речитативі, вимагала енергії, виразної декламації, поривчастості, темпераменту. 
Розглянемо яскравий і загадковий образ Матері - Азучени. В основу сюжету опери Дж. Верді покладено однойменну драму Антоніо Гарсіа Гутьєрреса, в центрі якого романтично-демонічний образ циганки Азучени, особливу увагу Верді приділив в опері саме їй. Адже спочатку цей твір мав назву «Смерть циганки». Помітний «демонізм» iii вигляду і поведінкової символіки вказує на ï партію як на епіцентр романтичної антиномічності виразу. I, зрозуміло, що ця роль, як правило, доручається першокласній співачці-актрисі, у голосі якої повинно бути закладено щирість, природність, теплоту як у виконанні речитативів, так і у виконанні арій.

Антиномічність цієї героїні очевидна на двох рівнях. Насамперед це проявляється у самому сценічному образі: Азучена не молода, вона «жахлива» у сприйнятті аристократів, але вона прекрасна в іiі відданості знедоленій матері, в іiі здатності жаліти і любити слабких і скривджених. Співачка повинна подбати про пластично-жестову переконливість краси Азучени, якщо віковий грим знімає печатку ідеальності з її сценічного обличчя.

Співачка повинна скрупульозно вивчити усю лінію ролі та, спираючись на лібрето й музикальну палітру, продемонструвати психологічні нюанси ролі, володіючи всіма технічними можливостями голосу. Насамперед у роботі повинно бути використано повний діапазон, ідеальне володіння piano i forte, чітка та виразна дикція, особливо для наповнення речитативів. Частіше, це співачка-актриса середнього віку, яка має великий досвід щодо виконання драматичних партій.

Пластика жесту-руху покликана фіксувати істоту величного вигляду жінки, що приймає стезю спокутування-жертви. Демонізм образу Азучени спрощує прочитання іï партії в бік злиття з тривіально-романтичним баченням. Тобто в художній ідеї цього образу значну роль відіграє взаємозв'язок зовнішнього і внутрішнього, видимого і невидимого, що в цілісності своєї являє смислове наповнення сценічного втілення. «Образ - серце мистецтва, а власне мистецтво - це спосіб мислення художніми образами», - роз'яснює Л.І. Ніколаєв у книзі «Художній образ як перетворена модель миру» [13].

«Від драматургічної основи твору залежать характеристики образу та технічні прийоми. Це доволі закономірно, оскільки спів, музика і є по суті засобом вираження емоційного стану 
людини, бесідою зі слухачем язиком почуттів та емоцій», зазначає професор В.П. Морозов [12, с. 191].

Другий рівень антиномічності образу Азучени необхідно співвіднести із зазначеною вище дуалістичністю жіночого образу, тільки дешо в іншому ключі. Героїня є в одній особі Донька, яка прагне помсти, і любляча Мати. У вокальній партії виразно прописаний смисловий поділ, частіше інтонаційно-мелодійним способом: Азучена і Монріко, Азучена і Мати.

Лаурі Вольпи не рекомендував виконувати декілька вистав поспіль, позаяк під час виконання накладається дуже велике психологічне навантаження на нервову систему співачки: «Неодноразове повторення драматичних епізодів приводить до руйнування нервової системи виконавиці ролі. В історії $\epsilon$ трагічні приклади, пов'язані з виконанням поспіль ролі Азучени» [9, с. 17].

Героїня представлена у Верді як прояв материнського начала, цьому доказ - особливості іiі музичної характеристики, в якій очевидні відмінності між «дочірніми» і «материнськими» переживаннями. Азучена - Дочка, яка бажає помсти, характеризується гострою ритмікою, експресивною мелодикою в крайніх регістрах діапазону і романтично-демонічним колоритом музичного висловлювання в загальному, яка набуває конкретної жанрової ознаки - баладності (2-а дія, Пісня і Розповідь). Коли Циганка в таборі веде свою розповідь, оркестр підкреслює iї агресивність. У цей момент Азучена у всій повноті представлена у вигляді Дочки, яка одержима спогадами про трагічну долю своєї матері і яка жадає помсти.

Однак, коли Азучена проявляється як любляча Мати, вигляд iï музичної характеристики істотно змінюється, зникає інтонаційна напруженість, спрощується ритм, зникають жанрові обриси баладності, що створюють демонічний образ героїні. Вона стає м'якшою, добрішою, змінюється емоційний тонус висловлювання. I на перше місце виступає згадана вище інтонація поступового сходження: ця ідея материнського покаяння заявлена на початку сцени із сином у 2-й дії, при цьому авторська ремарка вказує на пристрасність інтонування цих слів - це прояв внутрішньої Азучени люблячої і страждаючої Матері. У всіх сценах, де героїня проявляється як любляча мати, присутній спад щодо спрямованості мелодійної лінії, то явна, то більш завуальована, у не характерній для Азучени тональності g-moll. А в 3-й дії 
у згадці про сина, який покинув іiі, - знову спад мелодики і тут же екстатичний прояв материнського почуття 3 мелодійним злетом угору в E-dur.

Образ Матері - це завжди шанс для співачки продемонструвати драматичні можливості таланту, а також можливості свого голосу, як технічні прийоми piano, forte, так і тембральні багатства голосу. «Перш за все треба мати розум, потім гаряче серце та залізну волю і аж потім голос», - так стверджував видатний оперний співак та педагог О.П. Мишуга [10, с. 8].

Кульмінацією цієї лейтінтонації Азучени можна назвати заключну сцену із сином у в'язниці в момент спогадів про смерть своєї матері. У цьому моменті очевидний смисловий перетин двох образів героїні - Дочки і Матері, видів, які втілюють трагізм образу Азучени: страждає, кається і мститься одночасно. Антиномічність героїні парадоксальним чином відкривається і в момент смерті сина в заключній сцені: вона не оплакує його, це не валить іiі в жах, вона лише констатує те, що сталося: «За матір помстилося небо!». Складність образу Азучени полягає саме в його смисловій багатогранності, в його емоційно-психологічній багатоскладності, яка повинна спрямовувати перемикання співачки з одного обліку до іншого, що, відповідно, впливає на як зовнішню сторону сценічного втілення (жест, пластику, міміку), так і внутрішню (емоційне наповнення вокальної партії).

Після виконання такої складної партії, як Азучена в опері «Трубадур» Дж. Верді, я не один раз відчувала душевну порожнечу. Дуже важко відключити всі емоції, вигнати із серця і голови ті почуття, які шойно відчувала під час виконання цієї ролі, скинути з плечей той вантаж жахів, які Азучена розповідала Монріко. Але, якщо співати, не уявляючи та не співчуваючи, голос буде звучати холодно та непереконливо. Це нині нікому не потрібно та не цікаво.

«Спів - це щедре мистецтво, яке стоїть на службі у серця», казав Едмонд Дювернуа учениці Х. Даркле [5, с. 130]. Я думаю, що він мав на увазі, що жоден звук, жоден рух на сцені не повинен бути театральним спочатку, а повинен іти від серця й душі. Лише тоді ми побачимо правду життя на сцені, і це дорогого коштує. Слухач давно вже не хоче слухати красивий бездушний спів. Глядач бажає співпереживати, плакати, сміятися разом із співачкою та при цьому насолоджуватися красивим співом. 
Це означає, що «співачка ніколи не може обдурити слухача награною легкістю й невимушеністю свого виконання: ці властивості повинні бути дійсними, тобто які відчуває сама співачка», - писав професор В.П. Морозов [12, с. 171].

В.П. Морозов у своїй книзі ставить питання та знаходить відповідь: «Чого після прослуховування одного співака відчувається фізична втома і навіть біль у горлі, тоді як спів другого викликає бадьорість, добре фізичне самопочуття та навіть сильне бажання співати самому? У світі теорії активного сприйняття співу це знаходить своє пояснення: слухати спів - значить бути спільником у виконанні» [12, с. 172].

Багато цілей у виконавця, але ж і велика нагорода чекає за добре виконання завдань, поставлених роллю, - це щедрі аплодисменти! Коли за лаштунками стоять гримери, костюмери, робочі сцени зі сльозами на очах - це велика нагорода за роботу співачки! Повірте, вони на своєму віку бачили багато різних виконавців, талановитих та не дуже... Їхня оцінка завжди правдива!

Співак не може існувати у вакуумі, йому завжди необхідна оцінка його роботи, причому будь-яка, але обов'язково об'єктивна - від диригента, від режисера, навіть від глядача, який випадково потрапив на виставу. I ось, синтезуючи ці зауваження, думки, співак допрацьовує свою роль, звичайно ж, виходячи зі своїх відчуттів.

Коли я виконую партію Азучени, головне, що я хочу сказати людям, що за кожен вчинок слідує покарання і це потрібно завжди пам'ятати, як десять заповідей! Дж. Верді надав Азучені прекрасні вокальні мелодії ніжної люблячої Матері та Доньки. Але раптом вриваються теми помсти та жорстокості. Людина багатогранна і у почуттях теж. Цю боротьбу почуттів слухач споглядає протягом усієї вистави. В останній дії глядачам у дуеті Азучени і Монріко здається, що всі бурі стихли: «Ми знов побачимо рідні гори...». Дует - спомин про минуле вільне життя, звучить piano з посмішкою на обличчі. Наприкінці опери Азучена з посмішкою переможниці майже підводить риску своїй боротьбі - вона виконала прохання своєї матері: «Помстилася я за матір!». Глядачі у розпачі - невже перемагає зло? Азучена падає замертво, іiі покарано за злодіяння. Ще раз провидець Верді, гучно закінчуючи оперу на fortissimo, радить не сподіватися на безкарність дій. Таким чином я трактую образ Азучени в опері Дж. Верді «Трубадур». 
Висновки. Розглянутий приклад музично-сценічного образу Матері в опері західноєвропейського композитора Дж. Верді дозволяє класифікувати його за типом тембрового втілення це низький жіночий голос мецо-сопрано.

У цьому сенсі цілком очевидно, шо коли драматургічну концепцію образу являє зазначена психологічна дуалістичність героїні, композитор вибирає технічні можливості мецо-сопрано. Відповідно, можна говорити про виконавську типологію такого способу на рівні тембрової характеристики. Тобто багатогранність психологічного образу жінки-Матері вимагає відповідних якостей у музично-вокальному втіленні.

Якщо йдеться про втілення образу Матері в чистому вигляді, то тембральні характеристики мецо-сопрано цілком відповідають таким характеристикам материнського образу, як зрілість віку, врівноваженість характеру, стриманість в емоційних проявах. Розглянутий у цій статті образ Азучени дає змогу стверджувати, що для західноєвропейської художньої традиції більшою мірою характерне злиття в жіночому образі Доньки і Матері, що створює деяку смислову дуалістичність.

\section{СПИСОК ЛІТЕРАТУРИ}

1. Астафьев Б. Про оперу. Выборочные статьи. Ленинград, 1985. $336 \mathrm{c}$.

2. Волков Ю. Песни, опера, певцы Италии. Москва, 1967. 252 с.

3. Гачев Г.Д. Образ в художественной культуре. Москва, 1981. $247 \mathrm{c}$.

4. Гильбурд Г. Исполнительское искусство как сфера проявления художественной идеи. Томск, 1985. 195 с.

5. Даркле Х. Джорджа Сбирча. Первые шаги к славе. Бухарест, 1983. $130 \mathrm{c}$.

6. Дмитриев Л. Солисты театра Ла Скала об исскустве вокала: Диалоги о технике пения. Москва, 2002. 188 с.

7. Ерохина Т. Лик и личина: женские образы в исскустве символизма. URL: http://www.auditorium.ru.

8. Кириллина Л. Итальянская опера первой трети XX века: не только веризм. URL: http://www.21israel-music.com/Opera-XX.htm.

9. Лаури-Вольпи Дж. Вокальные паралели. 1972. 17 с.

10. Людкевич С. Олександр Мишуга як артист і вчитель співу. Львів, 1938. 8 с. $144 \mathrm{c}$.

11. Маркова О. Основы теории исполнительства. Одесса, 2002.

12. Морозов В.П. Тайны вокального языка. Ленинград, 1967. C. $171-191$. 
13. Ніколаєв Л.І. Художній образ як перетворена модель миру.

14. Самойленко А. Музыковедение и методология гуманитарного знания. Проблема диалога : монография. Одеса, 2002. 244 с.

15. Стахевич О.Г. Вокальне мистецтво Західної Європи: творчість, виконавство, педагогіка: дослідження. Київ, 1997. 272 с.

16. Черная О.С. Беседы про оперу. Москва, 1981. 158 с.

\section{REFERENCES}

1. Astafyev, B. (1985). About opera. Selected articles. Leningrad, 1985 [in Russian].

2. Volkov, Y. (1967). Songs, opera, singers of Italy. Moscow, 1967 [in Russian].

3. Gachev, G.D. (1981). Image in art culture. Moscow, 1981 [in Russian].

4. Gilburd, G. (1985). Performing arts as a sphere of manifestation of an artistic idea. Tomsk, 1985 [in Russian].

5. Darkle, H. George Sbircha (1983). The first steps to glory. Bucharest, 1983 [in Russian].

6. Dmitriev, L. (2002). Soloists of La Scala Theater on vocal art: Dialogues on the technique of singing. Moscow, 2002 [in Russian].

7. Yerokhina, T. Face and mask: female images in the art of symbolism. [electronic resource]. Retrieved from: http://www.auditorium.ru [in Russian].

8. Kirillina, L. Italian opera of the first third of the twentieth century: not only verismo. Retrieved from: http://www.21israel-music.com/ Opera-XX.htm. [in Russian].

9. Laurie-Volpy, J. (1972). Vocal parallels. 1972 [in Russian].

10. Lyudkevych, S. (1938). Alexander Mishuga, as an artist and singing teacher. Lviv, 1938. [in Ukrainian].

11. Markova, O. (2002). Fundamentals of the theory of performance. Odessa, 2002 [in Russian].

12. Morozov, V.P. (1967). Secrets of vocal language. Leningrad, 1967 [in Russian].

13. Nikolaev, L.I. Artistic image as a transformed model of the world [in Ukrainian].

14. Samoilenko, A. (2002). Musicology and methodology of humanities knowledge. The problem of dialogue. Monograph. Odessa [in Russian].

15. Stakhevich, O.G. (1997). Vocal art of Western Europe: creativity, performance, pedagogy: research. Kiev [in Ukrainian].

16. Chorna, O.S. (1981). Conversations about opera. Moscow [in Russian]. 